J. Dairy Sci. 95:2567-2570

http://dx.doi.org/10.3168/jds.2011-4946

(C) American Dairy Science Association ${ }^{\circledR}, 2012$.

\title{
Short communication: Effect of automatic postmilking teat disinfection and cluster flushing on the milking work routine
}

\author{
I. Ohnstad, ${ }^{1}$ R. G. M. Olde Riekerink,† P. Hogewerf,‡ C. A. J. M. de Koning,‡ and H. W. Barkema§ \\ *The Dairy Group, Taunton, TA1 2PX United Kingdom \\ †GD Animal Health Service, NL-7425SB Deventer, the Netherlands \\ łWageningen UR Animal Sciences Group, NL-8200AB Lelystad, the Netherlands \\ $\S$ Department of Production Animal Health, Faculty of Veterinary Medicine, University of Calgary, Calgary, AB T2N 1N4, Canada
}

\section{ABSTRACT}

The importance of a consistent and comprehensive milking routine as a critical component of any mastitis control program is well documented. However, as pressure on time increases, farmers are faced with 3 options: (1) adjust the milking routine to suit the time available, (2) undertake the task less thoroughly, or (3) examine which elements of the milking routine can be automated and substitute capital expenditure for labor. A study was undertaken on 5 farms in the United Kingdom in October and November 2007 to assess the effect on milking time of installing a commercial automatic postmilking teat disinfection and cluster back flushing system (ADF). Two of the farms recruited for the study were intending to purchase the ADF system in the near future and 3 farms had already invested in the technology. The farms ranged in size from 120 to 550 cows and included three $90^{\circ}$ rapid exit parlors, a herringbone parlor, and an abreast parlor. All 5 farms were visited for 2 successive milkings before the $\mathrm{ADF}$ was installed or disabled, and a detailed time and motion analysis was undertaken. After ADF was installed or the system reactivated, a further 2 milkings were monitored. All monitored farms showed a measurable reduction in milking time after the ADF system was installed. However, the magnitude of the reduction was greater than would be expected by simply removing the elements of postmilking teat disinfection and cluster sanitization. The benefits of ADF are greater than simply disinfecting teats and back flushing clusters and the time saving obtained may allow a more structured milking routine that may have additional benefits in terms of mastitis prevention and control.

Key words: postmilking teat disinfection, dipping, milking, time

Received September 16, 2011.

Accepted December 3, 2011.

${ }^{1}$ Corresponding author: ian.ohnstad@thedairygroup.co.uk

\section{Short Communication}

Dairy herds in Europe and North America have increased considerably in size over the past decade. This increase in herd size has not seen a comparative increase in staff numbers, which has resulted in a labor squeeze (Wall Street Journal, 2009). One consequence of this labor squeeze is an increase in pressure on staff through the working day and in particular at and around milking time. This has resulted in many farms compromising their mastitis control programs (Bradley, 2007).

The time associated with milking an individual cow (the work routine) is likely to be the largest determinant of the performance of the milking system, whether it is measured in terms of cows milked per hour or liters produced per hour (Baines, 2001). Farms are constantly examining their milking routines to streamline the operation and improve performance. However, it is important that the streamlining not occur at the expense of milk quality or udder health. Postmilking teat disinfection (PMTD) is a good example of this in practice (Pankey et al., 1984). Spraying of teats after milking using a hand-held lance has emerged as the most popular method of PMTD as dairy farms look to reduce the time spent on any element of the work routine; spraying takes about half the time of teat dipping (Burks et al., 2006). Although teat spraying may be quicker than teat dipping, most dairy practitioners recommend that teats be disinfected after milking by dipping. Dipping should ensure better teat coverage and better penetration of product into the teat canal. As a result, the incidence and prevalence of new IMI and bulk milk SCC are higher in herds that use spraying compared with dipping as a PMTD method (Barkema et al., 1998).

Many dairy farms in the United Kingdom faced with a contagious mastitis challenge have resorted to manually disinfecting the milking cluster after each animal (Bradley, 2007). Although farmers believe this practice helps to reduce cross infection, it adds considerably to the work routine, reducing milking system performance. 
Dairy farmers are increasingly interested in the application of technology to replace labor to work more efficiently (Wilson, 2011). If a technological solution can be applied to automate any task within the milking routine, the potential exists to improve milking system performance. Any improvement in the efficiency of the work routine could lead to a reduction in overall milking time, less stress on the operator and cows, or the release of time to concentrate on other essential elements of the routine. Clearly, the technology must be at least as consistent as the operator that it replaces.

An automatic postmilking teat disinfection and cluster back flushing system (ADF; ADF Milking Ltd., Slindon, UK) is designed to both disinfect the teat and sanitize the cluster between cows (Hogewerf et al., 2008). When the automatic cluster remover is activated, teat disinfectant is introduced into the hood of the liner while the liner is still located on the teat. As the liner is removed from the teat, disinfectant is applied to the teat surface. Once the liner is removed, the system goes through a series of flushes, alternating a peracetic acid solution with bursts of compressed air, to sanitize the liner surface. Similar systems have been described by Galton (2004) and Grindal and Priest (1989), in which the disinfectant is injected through the short milking tube or via a delivery tube within the long and short pulse tubes, respectively.

Several motivations may lead a dairy farmer to invest in technology such as ADF. These include expected improvements in individual cow and bulk milk SCC (our unpublished data), reduction in the incidence rate of new IMI, and improved efficiency in the milking routine. Improvements in udder health have also been described in earlier experimental studies with comparable but slightly different systems (Grindal and Priest, 1989; Galton, 2004). To quantify the potential efficiency gains that could be achieved by fitting $\mathrm{ADF}$, a detailed time and motion study was carried out during 20 milkings. Five dairy farms were studied during 2 consecutive milkings with and 2 consecutive milkings without an ADF installed. The means of the consecutive milking times with an ADF installed were compared with the means of the consecutive milking times without an ADF installed.

A milking technology specialist from The Dairy Group (Taunton, United Kingdom) visited 5 dairy farms during October and November 2007. The 5 farms selected included 2 new ADF installations and 3 existing users of the technology. A range of milking systems was selected (Table 1). Farms A and B were new users of ADF. These farms were visited for 2 consecutive milkings before the ADF system was installed. Once the system had been installed and commissioned, another visit was undertaken and 2 consecutive milkings observed. Farms C, D, and E were already users of the ADF system. These farms were visited for 2 consecutive milkings where they used the ADF system as designed. These farms were then asked to disable the ADF system and revert to their previous practice before installation of the ADF.

A full analysis of every operation carried out by the milkers was undertaken, and total time associated with each task was calculated (Armstrong and Quick, 1986). A rolling record of milking time was used to assess the time associated with cow loading, teat preparation, feeding, cluster attachment, PMTD, parlor unloading, cleaning equipment surfaces, and cleaning cow standings, with any time not attributed to a main task considered as miscellaneous.

Overall milking times for each farm without ADF installed varied between 122 and 271 min (Table 1). All values were rounded to the nearest minute. Milking time after the installation of the ADF system was reduced on all 5 farms visited and varied between 99 and $219 \mathrm{~min}$. However, when the data from each farm were examined, it became clear that some of the time savings were related to other elements of the milking

Table 1. Overall milking time with and without an automatic postmilking teat disinfection and cluster back flushing system (ADF) installed on 5 dairy farms in the United Kingdom

\begin{tabular}{|c|c|c|c|c|c|c|c|}
\hline \multirow[b]{2}{*}{ Farm } & \multirow[b]{2}{*}{ Parlor type } & \multirow[b]{2}{*}{$\begin{array}{l}\text { Herd } \\
\text { size }^{1}\end{array}$} & \multirow[b]{2}{*}{$\begin{array}{l}\text { Milkers, } \\
\text { no. }\end{array}$} & \multicolumn{2}{|c|}{$\begin{array}{l}\text { Mean milking time (min) } \\
\text { of } 2 \text { consecutive milkings }\end{array}$} & \multirow[b]{2}{*}{$\begin{array}{c}\text { Savings, min } \\
\text { (relative \%) }\end{array}$} & \multirow{2}{*}{$\begin{array}{c}\text { Time savings directly } \\
\text { attributable to ADF, min } \\
\text { (proportional to saving, \%) }\end{array}$} \\
\hline & & & & $\begin{array}{l}\text { No ADF } \\
\text { installed }\end{array}$ & $\begin{array}{c}\mathrm{ADF} \\
\text { installed }\end{array}$ & & \\
\hline A & 24/24 Rapid Exit & 277 & $1-2$ & 230 & 179 & $51(22)$ & $25(49)$ \\
\hline B & 24/24 Herringbone & 177 & 1 & 227 & 133 & $94(41)$ & $45(48)$ \\
\hline $\mathrm{C}$ & 16/32 Herringbone & 254 & 1 & 229 & 219 & $10(4.4)$ & $15(150)$ \\
\hline
\end{tabular}

${ }^{1}$ Lactating and dry cows. 
Table 2. Potential annual labor saving from reducing overall milking times after installing an automatic postmilking teat disinfection and cluster back flushing system (ADF) on 5 dairy farms in the United Kingdom

\begin{tabular}{|c|c|c|c|c|c|c|c|c|c|c|c|c|}
\hline \multirow[b]{2}{*}{ Farm } & \multirow[b]{2}{*}{$\begin{array}{c}\text { Herd } \\
\text { size }\end{array}$} & \multirow[b]{2}{*}{$\begin{array}{l}\text { Labor } \\
\text { units }\end{array}$} & \multicolumn{5}{|c|}{ Time and labor saved } & \multicolumn{5}{|c|}{ Time and labor saved directly attributable to ADF } \\
\hline & & & $\begin{array}{l}\text { Milking time } \\
\text { saved, min }\end{array}$ & $\begin{array}{l}\text { Labor, } \\
\min / \mathrm{d}\end{array}$ & $€ / d$ & $€ / \mathrm{yr}$ & $\begin{array}{l}€ / \text { cow } \\
\text { per yr }\end{array}$ & $\begin{array}{l}\text { Milking time } \\
\text { saved, min }\end{array}$ & $\begin{array}{l}\text { Labor, } \\
\min / \mathrm{d}\end{array}$ & $€ / d$ & $€ / y r$ & $\begin{array}{l}€ / \text { cow } \\
\text { per yr }\end{array}$ \\
\hline B & 177 & 1.0 & 94 & 188 & 31.3 & 11,437 & 65 & 45 & 90 & 15.0 & 5,475 & 31 \\
\hline $\mathrm{C}$ & 254 & 1.0 & 10 & 20 & 3.3 & 1,217 & 5 & 15 & 30 & 5.0 & 1,825 & 7 \\
\hline $\mathrm{D}$ & 120 & 1.3 & 23 & 60 & 10.0 & 3,638 & 30 & 17 & 44 & 7.4 & 2,689 & 22 \\
\hline
\end{tabular}

routine, such as loading the milking parlor, teat preparation, and miscellaneous time.

The saving in milking time that was directly attributable to automatic dipping of teats and cluster sanitation ranged between 15 and 62 min (Table 1). With the exception of farm $\mathrm{C}$, the reduction in time directly attributable to the installation of ADF ranged from 48 to $85 \%$ (Table 1). Although farm $\mathrm{C}$ demonstrated a 15-min reduction in milking time that could be directly attributable to $\mathrm{ADF}$, the farmer spent an extra $5 \mathrm{~min}$ washing the milking equipment, resulting in only a 10min reduction in overall milking time.

Farms A and B, with reductions in milking time approximately twice that expected by simply automating PMTD and cluster back flushing, both demonstrated a reduction in parlor loading time and miscellaneous time (Table 1). Although both farms A and B showed a reduction in overall milking time, time associated with teat preparation increased slightly, suggesting a more thorough cleaning.

The majority of the reduction in milking time noted on farms D and E (74 and 85\%, respectively) was associated with the practice of PMTD and cluster back flushing. Farm E was able to spend slightly longer on teat preparation, and cow loading and miscellaneous time decreased with both farms. Farm E manually disinfected every cluster after milking when the ADF system was not installed.

Of the farms visited, each farm showed a reduction in milking time following the installation of the $\mathrm{ADF}$ system. The potential time savings obtained on farm C was markedly less than that on other visited farms because the operator chose to spend additional time washing the external cluster surfaces. Previous studies showed a cow milking routine time reduction of $10 \%$ if PMTD was replaced by an automatic spraying system (Armstrong and Quick, 1986).

It was apparent that the milking routine was more structured and less erratic when milkings were monitored with the ADF operating. The automation of certain elements of the milking routine potentially re- leases time for the operator to assist with cow loading and adopt a more structured, more efficient milking routine. This may explain, in part, why reductions in overall milking time were observed beyond that directly associated with dipping teats and sanitizing clusters.

To quantify the labor saving from fitting ADF, an hourly labor charge of $€ 10 / h$ was used (I. Powell, The Dairy Group, Taunton, UK; personal communication). For the purpose of this calculation, we assumed that farms A and D used 1.3 labor units per milking (a labor unit was defined as a member of staff exclusively employed for the milk harvesting process; he/she was not involved in marshalling cows, feeding calves, or other associated tasks); farms B and C used 1.0 labor unit per milking; and farm E used 2.0 labor units per milking. The potential annual labor savings from reducing overall milking times ranged from $€ 1,217$ to $€ 17,763$ per year (Table 2). When this figure was considered on a per-cow basis, the potential benefits ranged from $€ 5$ to $€ 65$ per cow.

The labor saving that can be directly attributed to ADF ranged from $€ 1,825$ to $€ 15,087$ per year, with the labor saving on a per-cow basis ranging from $€ 7$ to $€ 31$ per cow (Table 2).

In conclusion, the 5 farms monitored all showed a reduction in overall milking time following the installation of the ADF system. When the reduction in milking time is considered, the potential to reduce labor costs exists. Reductions in overall milking time occurred beyond that expected directly by automating PMTD and cluster flushing. We suggest that some of the additional labor saving is obtained by a more structured and organized milking routine that is achieved following the automation of key components. In reality, capturing the labor saving is difficult when milking staff are paid a salary, although the reduction in milking time can be viewed as an opportunity to improve working conditions for staff, free up time for other tasks, or milk more animals. The scale of the benefit obtained from installing ADF was closely related to the milking routine previously used and the size of the herd. 


\section{ACKNOWLEDGMENTS}

The authors acknowledge the assistance and cooperation of the dairy farmers who took part in this study.

\section{REFERENCES}

Armstrong, D. V., and A. J. Quick. 1986. Time and motion to measure milking parlor performance. J. Dairy Sci. 69:1169-1177.

Baines, J. R. 2001. Choosing a milking parlour to minimise mastitis. Pages 39-44 in Proc. British Mastitis Conference, Stoneleigh, UK. Institute for Animal Health Compton, Compton, UK.

Barkema, H. W., Y. H. Schukken, T. J. G. M. Lam, M. L. Beiboer, H Wilmink, G. Benedictus, and A. Brand. 1998. Management practices associated with low, medium, and high somatic cell counts in bulk milk. J. Dairy Sci. 81:1917-1927.

Bradley, A. J. 2007. The way forward for UK mastitis control. Pages 25-32 in Proc. British Mastitis Conference, Stoneleigh, UK. Crown Publishing, Lincoln, UK

Burks, T. F., L. W. Turner, and W. L. Crist. 2006. Distribution fitting and parameterization of individual operator work routine times for small dairy parlors. J. Dairy Sci. 89:2343-2352.
Galton, D. M. 2004. Effects of an automatic postmilking teat dipping system on new intramammary infections and iodine in milk. J. Dairy Sci. 87:225-231.

Grindal, R. J., and D. J. Priest. 1989. Automatic application of teat disinfectant through the milking machine cluster. J. Dairy Res. 56:579-585.

Hogewerf, P. H., A. H. Ipema, C. J. A. M. de Koning, H. J. Schuiling, B. A. Slaghuis, V. Tancin, I. Ohnstad, and H. W. Barkema. 2008 Impact of automatic teat dipping and cluster flushing system on iodine residuals, milking characteristics and teat coverage. Pages 349-356 in Mastitis Control: From Science to Practice, T. J. G. M. Lam, ed. Wageningen Academic Publishers, Wageningen, the Netherlands.

Pankey, J. W., R. J. Eberhart, A. L. Cuming, R. D. Daggett, R. J. Farnsworth, and C. K. McDuff. 1984. Uptake on postmilking teat antisepsis. J. Dairy Sci. 67:1336-1353.

Wall Street Journal. 2009. Got workers? Dairy farms run low on labor. Even in recession, U.S. job candidates are scarce; milk producers relying on immigrants worry about a crackdown. Accessed Sept. 16, 2011. http://online.wsj.com/article/SB124890678343891639. html.

Wilson, P. 2011. Decomposing variation in dairy profitability: The impact of output, inputs, prices, labour and management. J. Agric. Sci. 149:507-517. 